\title{
New Insights into the Implication of Mitochondrial Dysfunction in Tissue, Peripheral Blood Mononuclear Cells, and Platelets during Lung Diseases
}

\author{
Marianne Riou ${ }^{1,2}$, Abrar Alfatni ${ }^{1}\left(\mathbb{D}\right.$, Anne-Laure Charles ${ }^{1}\left(\right.$, Emmanuel Andrès $\left.{ }^{3}{ }^{(}\right)$, \\ Cristina Pistea ${ }^{1,2}$, Anne Charloux ${ }^{1,2}$ and Bernard Geny ${ }^{1,2, *}$ \\ 1 University of Strasbourg, Translational Medicine Federation of Strasbourg (FMTS), Faculty of Medicine, \\ Team 3072 "Mitochondria, Oxidative Stress and Muscle Protection", 11 rue Humann, 67000 Strasbourg, \\ France; marianne.riou@chru-strasbourg.fr (M.R.); aaalfatni@hotmail.com (A.A.); \\ anne.laure.charles@unistra.fr (A.-L.C.); cristina.pistea@chru-strasbourg.fr (C.P.); \\ anne.charloux@chru-strasbourg.fr (A.C.) \\ 2 University Hospital of Strasbourg, Physiology and Functional Exploration Service, 1 Place de l'Hôpital, \\ CEDEX, 67091 Strasbourg, France \\ 3 Internal Medicine, Diabete and Metabolic Diseases Service, University Hospital of Strasbourg, \\ 1 Place de 1’Hôpital, CEDEX, 67091 Strasbourg, France; emmanuel.andres@chru-strasbourg.fr \\ * Correspondence: bernard.geny@chru-strasbourg.fr
}

Received: 29 February 2020; Accepted: 20 April 2020; Published: 26 April 2020

\begin{abstract}
Lung diseases such as chronic obstructive pulmonary disease, asthma, pulmonary arterial hypertension, or idiopathic pulmonary fibrosis are major causes of morbidity and mortality. Complex, their physiopathology is multifactorial and includes lung mitochondrial dysfunction and enhanced reactive oxygen species (ROS) release, which deserves increased attention. Further, and importantly, circulating blood cells (peripheral blood mononuclear cells-(PBMCs) and platelets) likely participate in these systemic diseases. This review presents the data published so far and shows that circulating blood cells mitochondrial oxidative capacity are likely to be reduced in chronic obstructive pulmonary disease (COPD), but enhanced in asthma and pulmonary arterial hypertension in a context of increased oxidative stress. Besides such PBMCs or platelets bioenergetics modifications, mitochondrial DNA ( $\mathrm{mtDNA}$ ) changes have also been observed in patients. These new insights open exciting challenges to determine their role as biomarkers or potential guide to a new therapeutic approach in lung diseases.
\end{abstract}

Keywords: lung diseases; mitochondria; blood; PBMCs; platelets; oxidative stress; COPD; asthma; pulmonary arterial hypertension; pulmonary fibrosis

\section{Introduction}

Lung diseases, especially chronic obstructive pulmonary disease (COPD), asthma, pulmonary arterial hypertension (PAH), and/or idiopathic pulmonary fibrosis (IPF) are main causes of mortality, resulting in significant health and economic burdens worldwide. Indeed, the prevalence of COPD is increasing with 64 million persons concerned in the world, and according to the latest WHO estimates, it will rise as the third leading cause of death by 2030 [1]. Asthma is the most common chronic disease among children, affecting around 235 million persons [2]. PAH or IPF are less common but are characterized by poor prognosis [3,4]. Based on this evidence, it appears important to gain new insight into lung diseases pathophysiology and to analyze potential biomarkers to better reveal lung function, diagnose, and predict the prognosis of these diseases. As observed during cardiovascular diseases, mitochondrial dysfunctions deserve to be further studied, both at the local and at the circulating levels [5]. Indeed, mitochondrial abnormalities are involved in lung diseases but direct evidence of 
mitochondrial dysfunction in human studies is limited, because of the difficulty to biopsy tissues in these frail patients.

Peripheral blood mononuclear cells (PBMCs) or platelets are accessible through a small amount of blood withdrawal and allow mitochondrial function analysis. PBMCs are composed by lymphocytes, monocytes, and dendritic cells, which mainly participate in immunity and inflammation. Platelets are known to modulate hemostasis and are also involved in pulmonary alterations. Isolation of circulating leukocytes is an easy way to represent cardiovascular stress [6-8]. Recent studies in sepsis have suggested that bioenergetics profiling of circulating PBMCs might reflect mitochondrial function in other tissues and are linked with disease grade, immune alterations, and prognosis [9-12]. At rest, PBMCs rely mainly on mitochondrial respiration to match the metabolic demand and show a significant spare respiratory capacity [13]. Compared to biopsy, blood withdrawal is easy, but isolating purified platelets is a time-consuming task and analyzing mitochondria from these platelets needs to be done in a timely and skillful manner [14]. Circulating platelets are rich in mitochondria and could be used to assess bioenergetics and systemic metabolism in pathologies such as diabetes, sepsis, and cardiovascular or sickle cell diseases [15-17]. Reactive oxygen species (ROS) is an important factor in platelet functioning [18], as observed in COPD and adult respiratory distress syndrome [19,20].

The mean bioenergetics profiles in human circulating platelets, monocytes, lymphocytes, and neutrophils were reported in real-time measurements of the mitochondrial oxygen consumption rate (OCR) using the extracellular flux analyzer (Seahorse Bioscience) [21]. In a healthy subject, monocytes are one of the most energetic cell types with high levels of both glycolysis and oxidative phosphorylation. Lymphocytes and platelets are more oxidative and less glycolytic at the basal state; neutrophils show little mitochondrial oxidative capacities [21]. The reserve capacity, difference between basal and maximal mitochondrial respiration, is potentially used by cells in the setting situations needing higher mitochondrial involvement and is about $20 \%$ in platelets, whereas it is highest in monocytes or lymphocytes.

Interestingly, despite red blood cells being present with no mitochondria in human, a recent report showed a presence of structurally cell-free competent mitochondria in blood circulation [22]. Circulating peripheral blood cells and plasma characteristics and bioenergetics are presented in Figure 1.
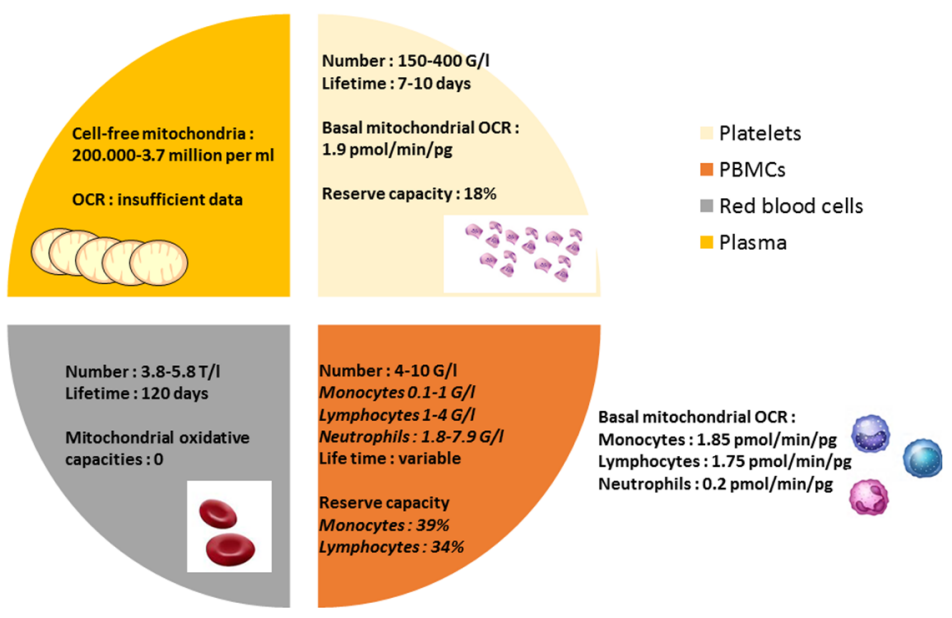

Figure 1. Characteristics of circulating blood cells and plasma: number, lifetime, and mitochondrial oxidative capacity. OCR: mitochondrial oxygen consumption rate.

The study of mitochondrial function in PBMCs and circulating platelets seems to be useful and complementary $[13,21]$. At present, the link between PBMCs or platelets mitochondrial function and lung diseases is poorly known and the objective of this review is to present the data published so far and to discuss the potential interest of studying circulating blood cells mitochondrial function and ROS production during COPD, asthma, $\mathrm{PAH}$, and IPF. 


\section{Physiological Mitochondrial Function}

Derived from ancient aerobic bacteria, mitochondria are double membrane structures with its own maternally DNA and transcription machinery. Mitochondria are involved in the heme biosynthesis, intracellular calcium regulation, ATP-production, and fatty acid synthesis. Mitochondria are the main source of energy in the cells and oxygen consumption by the mitochondrial respiratory chain (electron transport system-ETS) drives adenosine triphosphate (ATP) synthesis. Defects of mitochondria result in an energy deficiency that can impair cells, and lately the entire organism function. The mitochondrial respiratory system is located in the inner mitochondrial membrane and is formed by five complexes (I-IV and complex V-ATP synthase). Each complex can be analyzed with a spectrophotometer and, besides oxygen consumption, ATP synthesis and mitochondrial membrane potential can be determined [23,24]. Importantly, mitochondrial also generate ROS (i.e., anion superoxide arising from complexes I and III and dismutated to hydrogen peroxide by superoxide dismutase in hydrogen peroxide, which is able to leave the mitochondria), considered as signaling molecules at normal levels but able to generate proteins, lipids, and nucleic acids damages at higher levels [25].

Mitochondria contain DNA (mtDNA) and their own transcriptional mechanisms. MtDNA is very sensitive to oxidative stress and genotoxic agents because of its proximity to the mitochondrial respiratory chain, the major site of ROS production. If mtDNA is damaged, an increasing number of mtDNA copies appears as compensation and is believed as an indicator of mitochondrial function and oxidative stress [26]. After injury, mtDNA fragments accumulate in autolysosomes and are partially degraded by DNAse II.

\section{Mitochondrial Dysfunction in Lung Diseases}

Many of the lung diseases are thought to be related to aging, and accumulation of dysfunctional mitochondria is considered a marker for the pathological conditions but is also the key factor that drives disease progression. Thus, mitochondrial dysfunction may contribute to the pathogenesis of many human diseases including lung diseases such as COPD, asthma, PAH, and IPF [27,28], often associated with increased ROS and impaired bioenergetics and/or mitochondrial biogenesis, mitophagy, and dynamic, which are critical to maintain cell homeostasis and may result in cellular apoptosis and senescence [29]. Lungs are exposed to the high-oxygen environment and present huge contact areas with the blood to allow hematosis, making them sensitive to oxidative stress and damages. For example, tobacco smoking, a major risk factor for lung diseases, is linked to oxidative stress and induces mitochondrial dysfunction [30]. Mitochondrial ROS can favor pro-inflammatory cytokines secretion and modulate calcium regulation of epithelium and airway muscle cells or extracellular matrix production [31]. Lung parenchymal and immune cells communicate in response to infections, cigarette smoke, and air pollution etc., in order to repair tissues or defend against pathogen, but data on circulating blood cells are sparse.

In addition, some studies have suggested that mtDNA fragments could be implicated in lung diseases pathophysiology, acting as a damage-associated molecular pattern (DAMP) to initiate immunological response [32].

\subsection{Chronic Obstructive Pulmonary Disease (COPD)}

\subsubsection{Mitochondrial Dysfunction and Oxidative Stress in COPD}

COPD is a major cause of respiratory failure with a prevalence of $10 \%$ in adults over 40 years [1]. The estimates show that it will be the third cause of mortality in 2030. The pathogenesis of COPD is not completely understood. Chronic inflammation is a central feature, leading to airway remodeling, irreversible bronchial obstruction, and destruction of lung parenchyma (emphysema). Acute exacerbations, whatever their origin, increase oxidative stress and induce systemic inflammation both in lung resident and circulating cells of individual patients [33]. Oxidant-antioxidant imbalance is one of the involved mechanisms, but how mitochondrial mediated-inflammation contributes to the 
disease progression remains to be determined. Airway epithelium is very sensitive to oxidative stress because of a low expression of anti-oxidative enzymes which are sparsely inducible, mainly after tobacco exposure [34]. In COPD, oxidative stress is enhanced particularly after exacerbation. At the systemic level, plasmatic ROS are enhanced in smokers, whether or not with COPD, and oxidative capacity is lower in plasma of smokers. Wiegman et al. showed an association between mitochondrial dysfunction and excessive mtROS levels in airway smooth muscle cells from COPD patients, which contributes to enhanced inflammation and cell proliferation [31].

In COPD, mtROS are released from activated inflammatory cells or structural cells such as epithelial, endothelial, or smooth muscle cells [35]. In this way, oxidative stress is an adaptive response. It is a mechanism leading to initiate immune response to neutralize infectious agents and to maintain the cellular homeostasis [36]. In excess, ROS damages DNA, lipids, and proteins, resulting in lung cellular death, activation of metalloproteases, inactivation of antiproteases, and degradation of extracellular matrix which result in loss of alveolar units [37]. ROS participate also in cell proliferation and collagen synthesis in smooth muscle.

Moreover, ROS activate redox sensitive transcription factors such as nuclear factor-kappa B $(\mathrm{NF} \kappa \mathrm{B})$, resulting in release of pro-inflammatory mediators such as IL 1-like cytokines [36,38]. Levels of IL-1 $\beta$ are increased in lungs of patients with COPD after smoking, suggesting the involvement of inflammasome [38-40].

\subsubsection{Mitochondrial Function, Oxidative Stress, and mtDNA in PBMCs or Platelets in COPD}

PBMCs have been shown to release more ROS, which may contribute to COPD patient's prognosis [41]. A recent study observed a high level of mitochondrial dysfunction and derived ROS in PBMCs obtained from unstable COPD patients after combustion-generated ultrafine particles exposure [42]. Indeed, exposure to nano-organic carbon particles and soot ultrafine particles (found in environmental pollution) induced the release of pro-inflammatory IL-18 and IL-33 from exacerbated COPD-derived PBMCs, with oxidative stress. Further, a recent work observed that PBMCs in COPD have reduced ability to use glucose, pyruvate, or fatty acids at baseline, which is not observed in PBMCs from healthy smokers which have only impaired glycolysis [43]. Similar results have been observed in sepsis [44].

Because COPD is frequently associated with cardiovascular diseases, activation of blood platelets through inflammation seems to have an important role in the pathophysiology of COPD [19]. After respiratory exacerbation, thrombocytosis is associated with significantly short and long term mortality, supporting an important role of platelets [45]. Antiplatelet therapy may have a protective role in patients after exacerbation of COPD. A study has shown that, during COPD, hypercoagulation (measured through platelet distribution width) is associated with reduced survival [46]. In a guinea pig model, Bialas et al. showed increased proton and electron leaks and decreased mitochondrial respiratory chain capacity in platelets from chronic smoke-exposed animals [47]. Proton and electron leaks in platelets appeared related to ROS production and interactions between oxidative stress and platelets could represent potential therapeutic targets. Indeed, administration of $\mathrm{N}$-acetylcysteine improved the quality of life of stable COPD patients [48].

MtDNA levels can be modulated by oxidative stress in COPD, as observed in the exhaled breath or urine $[49,50]$. In leukocytes, mtDNA easily undergo mutations, insertions, or deletions in response to oxidative stress during COPD. Liu et al. showed a decreased peripheral leukocyte mtDNA copy number in COPD patients, suggesting a less mtDNA protection or biosynthesis in these patients [51]. Mitochondrial dysfunction could result in abnormal function of leukocytes in COPD. In this study, the mtDNA copy number was similar in healthy smokers and non-smokers subjects. On the contrary, a study showed an increase of mtDNA/nuclear DNA ratio in the blood from patients with ACOS (asthma-COPD overlap syndrome). Interestingly, there was a correlation between mtDNA and the number of smoked cigarettes [52]. The increase of mtDNA content could compensate the mitochondrial respiratory function decline due to oxidative damage or mutation in this pathology. 
In addition, Kim et al. demonstrated that peripheral leukocyte mtDNA copy numbers positively correlated with leukocytes telomeres length in elderly women, suggesting that telomere may relate to mitochondrial function [53]. Indeed, COPD patients have short leukocyte telomeres, associated with an increased risk of total and cancer mortality [54,55].

In summary, mitochondrial dysfunctions in PBMCs of COPD patients result likely in abnormal functionality, and mitochondrial pathophysiology represents an emerging research with potential promising therapeutic avenues (Table 1, Figure 2, modified from [56]).

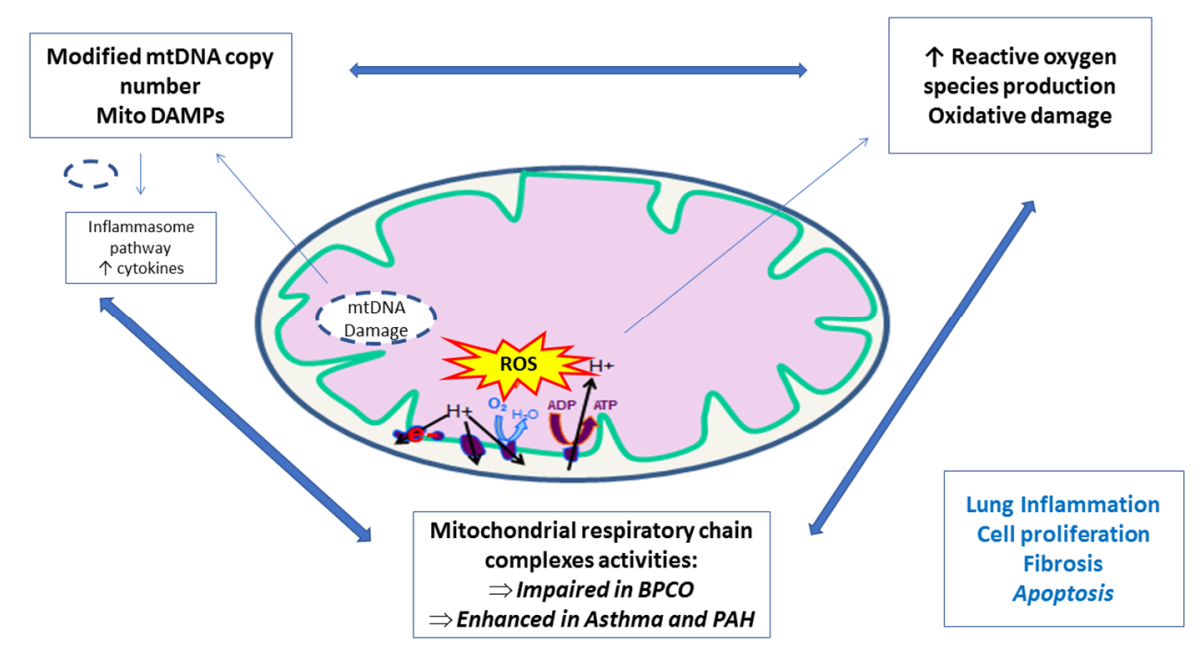

Figure 2. Peripheral blood mononuclear cells and platelets mitochondrial implication in lung diseases. 
Table 1. PBMCs or platelets mitochondria respiration is impaired in chronic obstructive pulmonary disease (COPD).

\begin{tabular}{|c|c|c|c|c|c|c|}
\hline References & $\begin{array}{c}\text { Lung Disease } \\
\text { Number of Patients }\end{array}$ & $\begin{array}{l}\text { Type of Circulating } \\
\text { Blood Cells }\end{array}$ & Mitochondrial Respiration & Oxidative Stress & mtDNA & Other Results \\
\hline $\begin{array}{l}\text { De Falco. 2017, Front } \\
\text { Immunol } \\
\text { [42] }\end{array}$ & Unstable COPD patients & $\begin{array}{c}\text { PBMCs } \\
\text { treated with } \\
\text { combustion-generated } \\
\text { ultrafine particles } \\
\text { exposure } \\
\end{array}$ & $\begin{array}{l}\text { High level of mitochondrial } \\
\text { dysfunction }\end{array}$ & $\begin{array}{l}\text { High level of mtROS } \\
\text { High expression of } \\
\text { NOD-like receptor } 3 \text { in } \\
\text { PBMCs in basal conditions } \\
\text { in COPD patients }\end{array}$ & & $\begin{array}{l}\text { Release of cytokines: } \\
\text { IL-18 and IL-33 } \\
\text { (dependent on the } \\
\text { release of caspase-4) }\end{array}$ \\
\hline $\begin{array}{c}\text { Bialas. 2018, } \\
\text { Int J Chron Obstruct } \\
\text { Pulmon Dis [47] }\end{array}$ & $\begin{array}{l}\text { Chronic smoke-exposed } \\
\text { guinea pig }\end{array}$ & Platelets & $\begin{array}{c}\text { Increased proton and } \\
\text { electron leak } \\
\text { Decreased electron transfer } \\
\text { system capacity }\end{array}$ & & & \\
\hline $\begin{array}{l}\text { Carpagnano. 2016, } \\
\text { BMC Pulm Med [52] }\end{array}$ & $\begin{array}{l}\text { ACOS patients }(n=23) \\
\text { COPD patients }(n=13) \\
\text { Asthmatic patients }(n=14) \\
\text { Normal subjects }(n=10)\end{array}$ & PBMCs & & & $\begin{array}{l}\text { Increased mtDNA/ } \\
\text { nuclear DNA ratio in } \\
\text { ACOS patients compared } \\
\text { to other groups } \\
\text { Increased mtDNA/ } \\
\text { nuclear DNA in } \\
\text { asthmatic or COPD } \\
\text { patients compared to } \\
\text { normal subjects }\end{array}$ & \\
\hline $\begin{array}{c}\text { Agarwal. 2019, Respir } \\
\text { Res } \\
{[43]}\end{array}$ & $\begin{array}{l}\text { Tobacco smoke related } \\
\text { COPD patients }(n=14) \\
\text { Non-smokers }(n=16) \\
\text { Healthy smokers }(n=13)\end{array}$ & PBMCs & $\begin{array}{l}\text { Impaired glucose metabolism } \\
\text { in COPD subjects: lower } \\
\text { OCR, ATP production, and } \\
\text { spare respiratory capacity } \\
\text { Impaired pyruvate } \\
\text { metabolism in COPD subjects } \\
\text { Impaired fatty acid } \\
\text { metabolism in COPD subjects }\end{array}$ & & & $\begin{array}{c}\text { Increase of } \\
\text { inflammatory } \\
\text { cytokine response } \\
(\text { IFN- } \gamma, \text { IL-17, TNF- } \alpha \\
\text { IL-5, IL-9, and IFN- } \alpha \text { ) }\end{array}$ \\
\hline $\begin{array}{l}\text { Liu. 2015, PloS One } \\
\text { [51] }\end{array}$ & $\begin{array}{l}\text { COPD patients }(n=86) \\
\text { Healthy smokers }(n=33) \\
\text { Non-smokers }(n=77)\end{array}$ & PBMCs & $\begin{array}{c}\text { Decreased serum glutathione } \\
\text { level in COPD }\end{array}$ & & $\begin{array}{l}\text { Decreased leukocyte } \\
\text { mtDNA copy number of } \\
\text { PBMCs in COPD } \\
\text { Linear correlation } \\
\text { between mtDNA copy } \\
\text { number and serum } \\
\text { glutathione level }\end{array}$ & \\
\hline
\end{tabular}

ACOS: asthma-COPD overlap syndrome; ATP: adenosine triphosphate; COPD: chronic obstructive pulmonary disease; OCR: oxygen consumption rate; PBMCs: peripheral blood mononuclear cells. 


\subsection{Asthma}

\subsubsection{Mitochondrial Function and Oxidative Stress in Asthma}

Asthma is a frequent disease that affects around 235 million persons [2], showing airflow obstruction, bronchial hyper-reactivity, and inflammation [57]. It is multifactorial, favored by individual/genetic and general/environmental parameters. The progression of bronchial epithelium damage is related to increased inflammation, favored by cytokines release. Mitochondrial dysfunction and enhanced oxidative stress participate in the pathophysiology of asthma through increased mucus secretion and impaired bronchial smooth muscles, as observed both in experimental and clinical studies [58-64]. Accordingly, a decreased antioxidative capacity inferred from reduced superoxide dismutase, gluthation peroxidase, or catalase activity was related to the gravity of asthma [34,61-63]. Interestingly, the role of ROS is not unequivocal depending on the cells involved. Thus, if it is generally accepted that ROS arising from epithelial and smooth muscle cells participate in lung injury and aggravate inflammation [64], ROS might be protective when present in the blood.

\subsubsection{Enhanced Mitochondrial Function and ROS Production in PBMCs or Platelets in Asthma}

Currently, during asthma, there are some data on the mitochondrial implication of peripheral blood circulating cells. In school-aged children with atopic asthma, antigen-specific IgE receptor expression was revealed on PBMCs [65]. In addition, future exacerbations were associated with the number of basophils during childhood acute wheeze/asthma [66]. Recently, Ederle et al. showed, in severe exacerbated asthmatic patients, an enhanced PBMCs mitochondrial respiration and increased ROS production compared to healthy volunteers [67]. Interestingly, the plasma of asthmatic patients stimulated similarly the PBMC's of control subjects, suggesting a mechanism of protection as proposed during septic shock [68]. On the contrary, PBMCs impaired mitochondrial function was observed early (6 hours) in patients with local allergic rhinitis after an acute nasal allergen challenge [69]. Likewise, PBMCs oxidative capacity was often reduced in cardiovascular diseases [7]. In the study of Ederle et al., obesity might have played a role. Indeed, PBMCs mitochondrial respiration tend to be enhanced in asthmatic patients presenting with a BMI $\geq 30 \mathrm{~kg} / \mathrm{m}^{2}$ [67] and differential bioenergetics in airway epithelial cells and platelets between lean and obese asthmatics was observed [70,71]. Of note, steroids mediate eosinophils apoptosis via a mitochondrial pathway, and such a link needs to be further studied since systemic steroid treatment longer than 24 hours did not influence the ROS production [72].

Increasing evidence suggests an important participation of platelets and their secretions (thromboxane, serotonin ... ) in the pathophysiology of allergic diseases and a potential role as key modulators of immunity. In patients with asthma, alterations in platelets secretion, expression of surface molecules such as IgE receptors, aggregation, and adhesion were observed $[73,74]$. Platelets activation in bronchoalveolar lavage was associated with airway hyperreactivity [75-77]. Platelets contribute also to the secretion of cytokines and can activate eosinophils [78,79]. Xu et al. showed increased Krebs cycle enzyme activity and less dependence on glycolysis in platelets of asthmatic patients [80]. Taken together, these data suggest a capacity for greater oxygen consumption and more efficient energy production in platelets of asthmatic patients (Table 2). 
Table 2. PBMCs or platelets mitochondria respiration is enhanced in asthmatic or in patients with pulmonary arterial hypertension (PAH).

\begin{tabular}{|c|c|c|c|c|c|c|}
\hline References & $\begin{array}{c}\text { Lung Disease } \\
\text { Number of Patients }\end{array}$ & $\begin{array}{l}\text { Type of Circulating } \\
\text { Blood Cells }\end{array}$ & Mitochondrial Respiration & Oxidative Stress & mtDNA & Other Results \\
\hline \multirow{2}{*}{$\begin{array}{l}\text { Ederle. 2019, J Clin } \\
\text { Med [67] }\end{array}$} & $\begin{array}{l}\text { Severe asthmatic patients with } \\
\text { severe exacerbation } \\
\qquad(n=20)\end{array}$ & \multirow{2}{*}{ PBMCs } & $\begin{array}{l}\text { Increased PBMCs mitochondrial } \\
\text { respiratory chain complexes activity in } \\
\text { asthmatic patients }\end{array}$ & $\begin{array}{c}\text { Increased ROS } \\
\text { production in the } \\
\text { blood of asthmatic } \\
\text { patients }\end{array}$ & & \\
\hline & Healthy volunteers $(n=20)$ & & $\begin{array}{l}\text { Mitochondrial respiratory chain } \\
\text { complexes activity in PBMCs is related } \\
\text { to plasma constituent }\end{array}$ & $\begin{array}{l}\text { ROS production is } \\
\text { related to plasma } \\
\text { constituent }\end{array}$ & & \\
\hline \multirow{2}{*}{$\begin{array}{l}\text { Winnica. 2019, Antiox } \\
\text { Redox Signal [71] }\end{array}$} & $\begin{array}{l}\text { Lean and obese, mild to moderate, } \\
\text { asthmatic patients }(n=16)\end{array}$ & \multirow[t]{2}{*}{ Platelets } & $\begin{array}{l}\text { Similar basal OCR in lean healthy and } \\
\text { asthmatic subjects } \\
\text { Increased basal OCR in asthmatic obese }\end{array}$ & \multirow{2}{*}{$\begin{array}{c}\text { Enhanced ROS } \\
\text { production in lean } \\
\text { and obese asthmatics }\end{array}$} & & \\
\hline & $\begin{array}{l}\text { Lean and obese healthy volunteers } \\
\qquad(n=21)\end{array}$ & & $\begin{array}{c}\text { Enhanced maximal OCR in lean and } \\
\text { obese asthmatic patients }\end{array}$ & & & \\
\hline \multirow[b]{3}{*}{$\begin{array}{l}\text { Nguyen. 2017, JCI } \\
\text { Insight [81] }\end{array}$} & & & Similar OCR in both groups & & & \\
\hline & $\begin{array}{l}\text { Asthmatic patients }(n=12) \\
\text { Healthy controls } \\
(n=13)\end{array}$ & Platelets & $\begin{array}{c}\text { Decreased glycolytic rate and greater } \\
\text { tricarboxylic acid cycle activity in } \\
\text { asthmatic platelets }\end{array}$ & & $\begin{array}{l}\text { No change in mtDNA } \\
\text { content }\end{array}$ & $\begin{array}{l}\text { No change in mitochondrial } \\
\text { number and morphology }\end{array}$ \\
\hline & $\begin{array}{l}\text { Group } 1 \text { PAH patients }(n=28) \\
\text { Control patients }(n=28)\end{array}$ & Platelets & $\begin{array}{l}\text { Increased glycolytic rate in PAH } \\
\text { patients: decrease of pyruvate } \\
\text { dehydrogenase activity } \\
\text { No change in basal respiration } \\
\text { Enhanced respiratory reserve capacity in } \\
\text { PAH dependent on increased fatty acid } \\
\text { oxidation } \\
\text { Increase in complex II enzymatic activity } \\
\text { and decrease in complex I enzymatic } \\
\text { activity. No change in enzymatic activity } \\
\text { of complex IV. }\end{array}$ & $\begin{array}{l}\text { No change in } \\
\text { mitochondrial } \\
\text { superoxide } \\
\text { production }\end{array}$ & & $\begin{array}{c}\text { Positive correlation between } \\
\text { respiratory reserve capacity } \\
\text { and hemodynamic severity } \\
\text { (mean PAP, PVR and right } \\
\text { ventricle stroke work index) } \\
\text { No change following } \\
\text { phosphodiesterase } 5 \\
\text { inhibitions, prostacyclin } \\
\text { analogue and endothelin } \\
\text { receptor antagonist }\end{array}$ \\
\hline $\begin{array}{l}\text { Nguyen. 2019, Plos } \\
\text { one. [82] }\end{array}$ & $\begin{array}{l}\text { Group } 2 \text { PH patients }(n=20) \\
\text { Control patients }(n=20)\end{array}$ & Platelets & $\begin{array}{l}\text { No significant difference in basal oxygen } \\
\text { consumption rate. } \\
\text { Increased maximal oxygen consumption } \\
\text { rate (increased contribution of fatty acid } \\
\text { and glucose oxidation). }\end{array}$ & $\begin{array}{l}\text { No difference in } \\
\text { mitochondrial } \\
\text { superoxide } \\
\text { production. }\end{array}$ & & $\begin{array}{l}\text { Negative correlation betweer } \\
\text { maximal mitochondrial } \\
\text { respiration and right } \\
\text { ventricular stroke work inde } \\
\text { No change following nitrite } \\
\text { inhalation. }\end{array}$ \\
\hline
\end{tabular}

ETC: electron transport chain; OCR: oxygen consumption rate; PAH: pulmonary arterial hypertension; PAP: pulmonary arterial pressure; PVR: pulmonary vascular resistance. 


\subsection{Pulmonary Hypertension}

\subsubsection{Mitochondrial Dysfunction, ROS, and mtDNA in Pulmonary Hypertension}

Pulmonary hypertension $(\mathrm{PH})$ is classified in five groups, depending on hemodynamic characteristics [83,84]. Post-capillary PH (group 2) is secondary to left heart diseases [83]. In left heart diseases, PBMCs undergo changes similar to failing cardiomyocytes and the degree of PBMCs mitochondrial dysfunction and increased ROS can be related to the disease severity [6-8,85-87]. Classically, group 1 of $\mathrm{PH}$, which includes idiopathic pulmonary arterial hypertension (PAH), is characterized by pulmonary artery remodeling with intimal fibrosis, medial smooth cells hypertrophy, and in situ thrombosis with plexiform lesions. This arterial remodeling is associated with elevated pulmonary vascular resistance, potentially leading to right ventricular failure and death [88] and we can expect a potential implication of mitochondrial impairment and ROS in PAH.

Particularly, they favor vessels constriction progression through wall thickening via growth factor stimulation and endothelin-1-related smooth muscle proliferation [89-93]. Hypoxic response, inflammation, apoptosis, and vasoconstriction in PAH might also use endothelial mitochondria pathways. In animals and humans, endothelial and pulmonary arterial smooth muscle cells exhibit metabolic switch from mitochondrial oxidative phosphorylation toward cytoplasmic glycolysis even in the presence of oxygen, conferring apoptosis resistance and cellular hyper proliferation [94,95]. This is accompanied by altered mitochondrial ETC activity [94]. These abnormalities concern also cardiac tissue and cells as well as skeletal muscle of PH patients [96-101]. Further, altered BMPR2 expression, gene implicated in $\mathrm{PAH}$ predisposition, was linked to pulmonary arterial endothelium mitochondrial dysfunction [102] and ROS upregulate hypoxia-inducible transcription factors [103,104].

Oxidative stress further enhances vasoconstriction through endothelin-1 and thromboxane A2, increased hypoxic cytosolic calcium concentration, and reduces vasodilatation through decreased prostacyclin production [105-107]. Accordingly, anti-oxidative therapies are beneficial in experimental PAH $[108,109]$. ROS are produced by inflammatory and vascular cells, and NADPH oxidases are localized in macrophages or polynuclear as well in pulmonary arterial endothelial, smooth muscle cells, and fibroblasts [110-112].

Moreover, studies suggested that mtDNA injury participates in PAH development. The mitochondrial Sirtuin 3, involved in mtDNA repair, is decreased in PAH patients and monocrotaline-induced $\mathrm{PH}$ in rats $[113,114]$.

\subsubsection{Mitochondrial Function in Platelets during Pulmonary Hypertension}

In PAH, platelets participate in vascular thrombosis through different mechanisms $[115,116]$. Very interestingly, Nguyen et al. showed that circulating platelets from PAH patient's exhibit impaired bioenergetics characterized by increased glycolysis compared to healthy controls [81], Table 2. In these patients, increased glycolysis was associated with a switch toward fatty acid oxidation, and increased respiratory reserve capacity correlated with the hemodynamic severity assessed by right heart catheterization. This suggests a relationship between platelet mitochondrial function and PAH severity. In this study, PAH pulmonary vasodilators modulating endothelin, nitric oxide, and/or prostacyclin activities did not affect the mitochondrial bioenergetics observed in PAH platelets, but this deserves to be confirmed in a greater subset of patients.

It might be useful to investigate a potential link between brain natriuretic peptide (BNP), an established biomarker of PAH severity and prognosis, and platelet bioenergetics alteration which could also reflect abnormalities of pulmonary vascular cells or cardiomyocytes and could be useful to assess PAH gravity and progression. Further, since BNP has been shown to protect cardiac and skeletal muscles mitochondria from ischemia-reperfusion damages $[117,118]$, it might be interesting to investigate whether BNP might also modulate circulating cells oxidative capacities.

Interestingly unlike in PAH (group 1), platelets from subjects with HF with preserved ejection fraction (group $2 \mathrm{PH}$ ) did not show change in the glycolytic rate compared to normal subjects [82]. 
However, similarly to PAH patients, they showed an enhanced maximal respiratory capacity. Besides $\mathrm{HF}$, older age and other comorbidities such as obesity, diabetes, or systemic hypertension might explain in part the observed differences in platelet biology.

\subsection{Idiopathic Pulmonary Fibrosis and Interstitial Lung Diseases}

Mitochondrial Dysfunction, Oxidative Stress, and Inflammation in Idiopathic Pulmonary Fibrosis

Interstitial lung diseases are characterized by progressive scarring of the lungs. Mechanisms underlying the pathogenesis of these diseases remain incompletely understood and idiopathic pulmonary fibrosis (IPF) is the most common fibrotic interstitial lung disease. Despite anti-fibrotic treatments, IPF has a poor prognosis with a life expectancy of 3-5 years after the diagnosis, which is generally made in patients older than 60 years [3]. A characteristic feature of IPF is the accumulation of myofibroblasts arising from normal lung fibroblasts, largely involved in extracellular matrix remodeling, in response to biochemical courses such as TGF- $\beta$ (a pro-fibrotic cytokine) or environmental/genetic factors [119].

Recent studies suggested a role of mitochondrial dysfunction in term of biogenesis, dynamic (fusion or fission), and mitophagy in the physiopathology of IPF. There is evidence for mitochondrial dysfunction leading to cellular senescence and apoptosis in alveolar epithelial cells (AECs), fibroblasts, and immune cells, participating in the fibrotic process. Besides a potential role of age per se, mitochondrial dysfunction being a recognized hallmark of aging, the alveolar epithelium is sensitive to injury/apoptosis induced by cigarette smoke and other pollutants, which may affect AECs mitochondrial function. TGF- $\beta$ also regulates the alterations of mitochondrial function [120-122].

There is an enhanced mtROS production in fibrotic lungs leading to type II AECs apoptosis, but lung macrophages and fibroblasts are resistant to apoptosis. Mitochondria from fibrotic type II AECs change their shape and become enlarged but mitophagy and biogenesis are reduced. In lung macrophages, altered mitochondria are removed via mitophagy and undergo fission. In fibrotic myofibroblasts, mitochondrial dysfunction has been termed "mitochondrial dysfunction-associated senescence," characterized by a distinctive senescence-associated secretory phenotype. Fibrotic fibroblasts present with reduced mitophagy and mitochondrial biogenesis but with enhanced fission. MtROS generated at complex III could be responsible for excessive TGF- $\beta$ in IPF since they are involved in TGF- $\beta$ mediated gene expression [123].

Regarding these data, antioxidants could be beneficial in IPF. However, a randomized clinical trial testing $\mathrm{N}$-acetylcysteine failed to improve lung function, rate of death, or acute exacerbations ratio in IPF patients, suggesting the role of other associated factors in IPF development [124]. Mitochondrial targeted antioxidant could reduce TGF- $\beta$ induced pro-fibrotic gene expression and NOX-4 expression, which is necessary for TGF- $\beta$ induced-myofibroblast differentiation [123].

To date, no work has studied the mitochondrial function in PBMCs or platelets in IPF. A study of circulating fibrocytes oxidative capacity, which are derived from monocytes lineage and thought to be precursors of fibroblasts, could be interesting [125]. Because epidemiological studies showed a link between IPF and cardiovascular diseases or venous thromboembolism, studying mitochondrial function in platelets could also be helpful in these diseases; platelet hyperactivity in patients with IPF being recently demonstrated [126,127].

\section{Connections between Mitochondrial Dysfunction, ROS, and Inflammatory/Fibrotic Pathways in Lung Diseases. Pathophysiological Hypothesis}

Such connections are numerous and besides other pathways, mitochondrial membrane polarization changes, altered mitophagy, and damage-associated molecular patterns (DAMPS)-related signaling can be involved in alveolar or pulmonary vascular remodeling observed in lung diseases. For clarity, these pathways are presented separately but they often share mutual mechanisms in COPD, PAH, asthma, and/or IPF (Figure 3). 


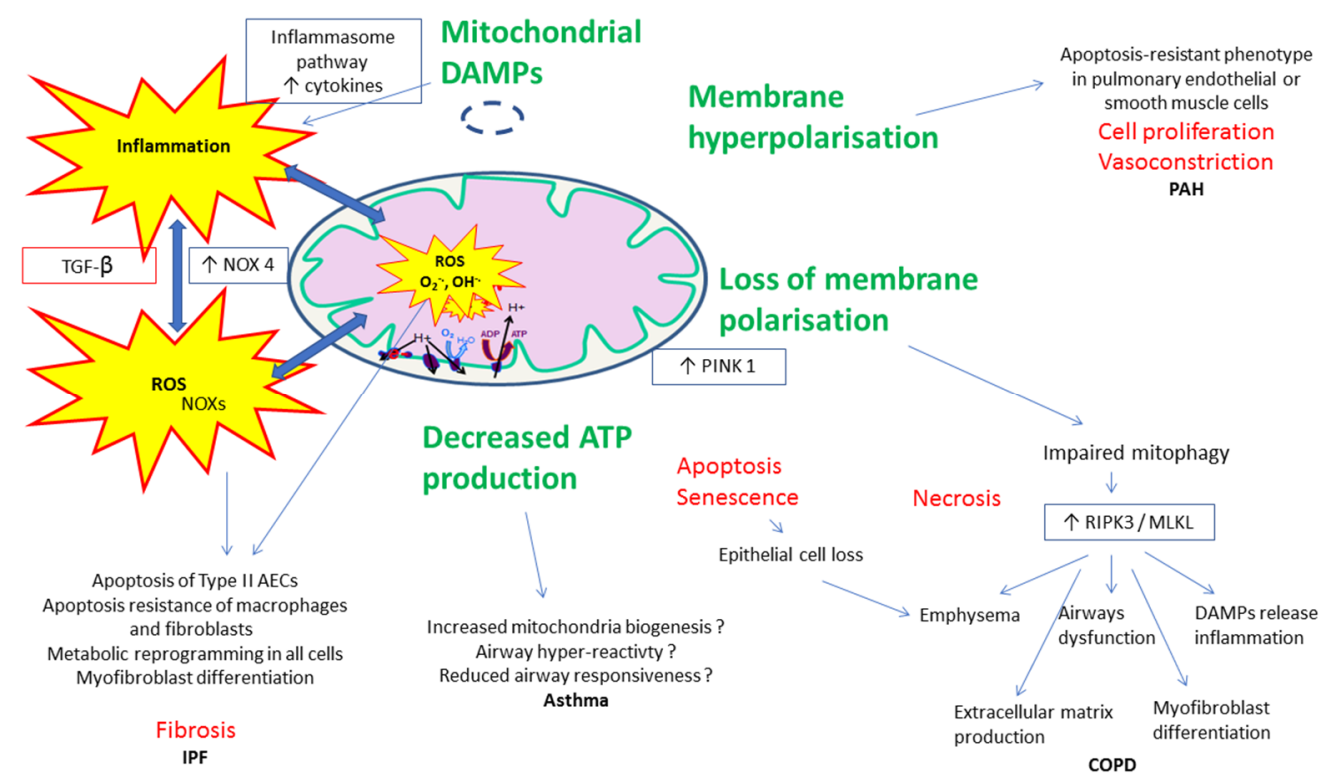

Figure 3. Examples of proposed mechanisms involved in the connections between mitochondrial dysfunction, reactive oxygen species (ROS), and inflammatory/fibrotic pathways in lung diseases.

In PAH, for instance, mitochondrial dysfunction and impaired ATP production promote glycolysis and thus hyperpolarization of the inner mitochondrial membrane, preventing the release of proapoptotic factors and leading to an "apoptosis-resistant" phenotype in pulmonary endothelial or smooth muscle cells. This results in cell proliferation and vasoconstriction [128,129]. Additionally, inhibitors of apoptosis are released from mitochondria when cells are under stress.

In COPD, loss of membrane polarization and elevated expression of the mitophagy regulator protein PINK1 (phosphatase and tensin homolog-induced putative kinase 1), a serine/threonine kinase, in epithelial cells in emphysematous regions of human lungs coincides with increased expression of the protein RIPK3 (receptor-interacting protein kinase 3) which modulates the programmed necrosis and many features characterizing this chronic lung disease [130]. Programmed necrosis (necroptosis) is a cellular program regulated by RIPK1 (receptor-interacting protein kinase 1) and RIPK3, and MLKL (mixed lineage kinase domain-like pseudokinase) in chronic lung diseases.

In asthma, conflicting results have been reported. Thus, decreased ATP production has been reported either to reduce airway constriction which is an energy dependent mechanism, or to be associated with airway smooth muscle thickening [131].

In IPF, the mitochondrial quality control system plays various roles depending on pulmonary cell types. While type II alveolar epithelial cells, lung macrophages, and fibroblasts show increased mtROS production in fibrotic lungs, their response differs. Type II AECs undergo apoptosis but lung macrophages and fibroblasts display apoptosis resistance. In response to increasing oxidative stress, all three cell types undergo a metabolic reprogramming which leads to the development and progression of lung fibrosis. Particularly, fibroblasts are transformed into a myofibroblast state, the effector cells of IPF [132-134].

Damage-associated molecular patterns (DAMPs), generated and released by cellular injury, may trigger inflammation, apoptosis, and innate immune responses by activating pattern recognition receptors. Mitochondria-associated DAMPs include mtDNA, which through auto-, paracrine and/or systemic effects activate the inflammasome pathway, resulting in increased cytokine release by immune cells as well resident cells favoring this inflammation, cell proliferation, and apoptosis. Mitochondrial DAMPs can be considered as proinflammatory inductors of the pulmonary remodeling observed in lung diseases and have been correlated to mortality in diseases such as sepsis and IPF. Their precise role in COPD, asthma, or PAH still deserves further studies [29,135]. 
Of note, ROS do not only arise from mitochondria in lung tissue. The NADPH oxidase homolog NOX4 is overexpressed in the lungs, primarily in myofibroblasts in fibroblastic foci and remodeled blood vessels, but also in epithelial cells associated with aberrant bronchiolization. NOX4 induction is largely mediated by production of the pro-fibrotic growth factor TGF- $\beta$. NOX 4 also induces mitochondrial ROS production. The production of ROS promotes mitochondrial DNA damage by reducing the mitochondrial expression of mitochondrial sirtuin 3 and OGG1 to mediate alveolar epithelial cells apoptosis $[136,137]$. It is the same in PAH, NADPH oxidase homologs NOX 2 and NOX 4 are key producers of ROS in vasculature. Like in IPF, NOX 4 mediates TGF- $\beta 1$ dependent pulmonary vascular remodeling [138]. NOX 4 also mediates the effect of platelet-derived growth factor (PDGF) and HIF- $1 \alpha$ which are critical to the pathogenesis of PAH.

Hypoxia, a frequent condition in lung diseases, induces the production of mitochondrial-derived oxygen-free radicals and ROS by the mitochondrial ETC. Of the molecules involved in this process, $\mathrm{H}_{2} \mathrm{O}_{2}$ can activate the transcription factor and lower oxygen-induced factor HIF- $1 \alpha$, which is implicated in pathophysiology of the lung diseases like PAH. Chen et al. showed that HIF-1 $\alpha$ promoted pulmonary arterial smooth muscle cell proliferation and inhibited hypoxia-induced apoptosis, possibly through the regulation of mitochondrial dynamics [139].

Another mechanism which leads to mitochondrial dysfunction in PAH is the nitic oxide (NO)-cyclase guanylate- cyclic GMP pathway. NO regulates cellular respiration and mitochondrial biogenesis. In PAH, decreased NO level is associated with mitochondrial impairment with decreased ATP levels and dysregulated endothelial angiogenesis [140].

\section{Antioxidative Therapies}

Despite a clear involvement of ROS in lung diseases physiopathology, and albeit antioxidants appeared beneficial in experimental models, treatment with antioxidants has been largely unsuccessful and is not part of standard care in humans. Indeed, although improving some functional parameters, $\mathrm{N}$-acetylcysteine or nutrients rich in antioxidants showed generally no beneficial effect on the rate of adverse events or death rates $[124,141,142]$. The failure of trials might have resulted from an incomplete understanding of the role of mitochondrial ROS in lung diseases development. Indeed, mitochondrial ROS are not always detrimental. They could play a protective role at lower levels and act differently according to the redox microenvironment, which varies spatially and temporally in different subcellular compartments and in different cell types. Thus, only specific subsets of patients might benefit from antioxidant therapies, an individual's susceptibility potentially depending on variation in their antioxidant genes.

\section{Conclusions}

Mitochondrial dysfunction associated with lung inflammation and oxidative stress contributes to $\mathrm{COPD}$, asthma, $\mathrm{PAH}$, and idiopathic pulmonary fibrosis. To allow adequate function and maintenance of intracellular homeostasis, mitochondria rely on quality control pathways (mitochondrial biogenesis, fusion/fission, mitophagy ... ), and their alteration disrupts organelle metabolism and biogenesis, inflammation adequacy, and even innate immunity. The general concept that enhanced oxidative metabolism drives toward an anti-inflammatory response and that shifting toward a glycolytic metabolism favor an inflammatory response varies depending on the cells. Mitochondria are also platforms for pattern recognition receptors signal transduction and mediators in effector responses. Thus, mitochondrial DAMPS can activate the NRLP3 inflammasome, resulting in proinflammatory cytokine release. They act as the danger signal recognized by immune receptors $[131,143,144]$. Accordingly, for instance, TLR9 is involved in mtDNA induced in acute and chronic lung inflammation, through the TLR9-p38 MAPK pathway and STING pathway, respectively [145]. All pulmonary cell types are involved in the triad mitochondrial dysfunction-inflammation-enhanced ROS production.

Besides the role of mitochondrial dysfunction and oxidative stress at the tissue levels, studying PBMCs or the platelet's redox state takes roots on the fact that these cells play a key role in the 
inflammatory and immune mechanisms involved in lung diseases. Likely, an altered redox state of dysfunctional circulating blood cells could enhance oxidative stress at the tissue level, potentially worsening the progression of the disease. However, to date, it appears that despite a generally increased ROS production, mitochondria respond quite differently depending on the lung disease. Thus, an impaired mitochondrial oxidative capacity is observed in the case of COPD, but PBMCs and/or platelets mitochondrial respiration is enhanced in the setting of asthma or PH. Whether such stimulated oxidative capacities might be protective, deserves to be determined.

Further studies are needed to reinforce the current evidence and to identify the potential of circulating PBMCs or platelets as biomarkers, which might allow a better understanding of the mechanisms involved in lung diseases, a better follow-up of patients, and possibly might help to identify novel original therapies.

Funding: This research received no external funding.

Acknowledgments: We are grateful to Anne-Marie Kasprowicz for skillful assistance.

Conflicts of Interest: The authors declare no conflict of interest.

\section{References}

1. Lopez-Campos, J.L.; Tan, W.; Soriano, J.B. Global burden of COPD. Respirology 2016, 21, 14-23. [CrossRef] [PubMed]

2. Loftus, P.A.; Wise, S.K. Epidemiology and economic burden of asthma. Int. Forum Allergy Rhinol. 2015, 5, S7-S10. [CrossRef] [PubMed]

3. Tran, T.; Sterclova, M.; Mogulkoc, N.; Lewandowska, K.; Muller, V.; Hajkova, M.; Kramer, M.R.; Jovanovic, D.; Tekavec-Trkanjec, J.; Studnicka, M.; et al. The European MultiPartner IPF registry (EMPIRE): Validating long-term prognostic factors in idiopathic pulmonary fibrosis. Respir. Res. 2020, 21, 11. [CrossRef] [PubMed]

4. Hurdman, J.; Condliffe, R.; Elliot, C.A.; Davies, C.; Hill, C.; Wild, J.M.; Capener, D.; Sephton, P.; Hamilton, N.; Armstrong, I.J.; et al. ASPIRE registry: Assessing the spectrum of pulmonary hypertension identified at a REferral centre. Eur. Respir. J. 2012, 39, 945-955. [CrossRef] [PubMed]

5. Alfatni, A.; Riou, M.; Charles, A.-L.; Meyer, A.; Barnig, C.; Andres, E.; Lejay, A.; Talha, S.; Geny, B. Peripheral blood mononuclear cells and platelets mitochondrial dysfunction, oxidative stress, and circulating mtdna in cardiovascular diseases. J. Clin. Med. 2020, 9. [CrossRef] [PubMed]

6. Coluccia, R.; Raffa, S.; Ranieri, D.; Micaloni, A.; Valente, S.; Salerno, G.; Scrofani, C.; Testa, M.; Gallo, G.; Pagannone, E.; et al. Chronic heart failure is characterized by altered mitochondrial function and structure in circulating leucocytes. Oncotarget 2018, 9, 35028-35040. [CrossRef] [PubMed]

7. Li, P.; Wang, B.; Sun, F.; Li, Y.; Li, Q.; Lang, H.; Zhao, Z.; Gao, P.; Zhao, Y.; Shang, Q.; et al. Mitochondrial respiratory dysfunctions of blood mononuclear cells link with cardiac disturbance in patients with early-stage heart failure. Sci. Rep. 2015, 5, 10229. [CrossRef]

8. Ijsselmuiden, A.J.J.; Musters, R.J.P.; de Ruiter, G.; van Heerebeek, L.; Alderse-Baas, F.; van Schilfgaarde, M.; Leyte, A.; Tangelder, G.-J.; Laarman, G.J.; Paulus, W.J.; et al. Circulating white blood cells and platelets amplify oxidative stress in heart failure. Nat. Clin. Pract. Cardiovasc. Med. 2008, 5, 811-820. [CrossRef]

9. Adrie, C.; Bachelet, M.; Vayssier-Taussat, M.; Russo-Marie, F.; Bouchaert, I.; Adib-Conquy, M.; Cavaillon, J.M.; Pinsky, M.R.; Dhainaut, J.F.; Polla, B.S.; et al. Mitochondrial membrane potential and apoptosis peripheral blood monocytes in severe human sepsis. Am. J. Respir. Crit. Care Med. 2001, 164, 389-395. [CrossRef]

10. Belikova, I.; Lukaszewicz, A.C.; Faivre, V.; Damoisel, C.; Singer, M.; Payen, D. Oxygen consumption of human peripheral blood mononuclear cells in severe human sepsis. Crit. Care Med. 2007, 35, 2702-2708. [CrossRef]

11. Garrabou, G.; Moren, C.; Lopez, S.; Tobias, E.; Cardellach, F.; Miro, O.; Casademont, J. The effects of sepsis on mitochondria. J. Infect. Dis. 2012, 205, 392-400. [CrossRef] [PubMed]

12. Kraft, B.D.; Chen, L.; Suliman, H.B.; Piantadosi, C.A.; Welty-Wolf, K.E. Peripheral blood mononuclear cells demonstrate mitochondrial damage clearance during sepsis. Crit. Care Med. 2019, 47, 651-658. [CrossRef] [PubMed] 
13. Kramer, P.A.; Ravi, S.; Chacko, B.; Johnson, M.S.; Darley-Usmar, V.M. A review of the mitochondrial and glycolytic metabolism in human platelets and leukocytes: Implications for their use as bioenergetic biomarkers. Redox Biol. 2014, 2, 206-210. [CrossRef] [PubMed]

14. Zharikov, S.; Shiva, S. Platelet mitochondrial function: From regulation of thrombosis to biomarker of disease. Biochem. Soc. Trans. 2013, 41, 118-123. [CrossRef]

15. Avila, C.; Huang, R.J.; Stevens, M.V.; Aponte, A.M.; Tripodi, D.; Kim, K.Y.; Sack, M.N. Platelet mitochondrial dysfunction is evident in type 2 diabetes in association with modifications of mitochondrial anti-oxidant stress proteins. Exp. Clin. Endocrinol. Diabetes 2012, 120, 248-251. [CrossRef]

16. Sjovall, F.; Morota, S.; Hansson, M.J.; Friberg, H.; Gnaiger, E.; Elmer, E. Temporal increase of platelet mitochondrial respiration is negatively associated with clinical outcome in patients with sepsis. Crit. Care 2010, 14, R214. [CrossRef]

17. Cardenes, N.; Corey, C.; Geary, L.; Jain, S.; Zharikov, S.; Barge, S.; Novelli, E.M.; Shiva, S. Platelet bioenergetic screen in sickle cell patients reveals mitochondrial complex $\mathrm{V}$ inhibition, which contributes to platelet activation. Blood 2014, 123, 2864-2872. [CrossRef]

18. Chen, S.; Su, Y.; Wang, J. ROS-mediated platelet generation: A microenvironment-dependent manner for megakaryocyte proliferation, differentiation, and maturation. Cell Death Dis. 2013, 4, e722. [CrossRef]

19. Maclay, J.D.; McAllister, D.A.; Johnston, S.; Raftis, J.; McGuinnes, C.; Deans, A.; Newby, D.E.; Mills, N.L.; MacNee, W. Increased platelet activation in patients with stable and acute exacerbation of COPD. Thorax 2011, 66, 769-774. [CrossRef]

20. Bozza, F.A.; Shah, A.M.; Weyrich, A.S.; Zimmerman, G.A. Amicus or adversary: Platelets in lung biology, acute injury, and inflammation. Am. J. Respir. Cell Mol. Biol. 2009, 40, 123-134. [CrossRef]

21. Chacko, B.K.; Kramer, P.A.; Ravi, S.; Johnson, M.S.; Hardy, R.W.; Ballinger, S.W.; Darley-Usmar, V.M. Methods for defining distinct bioenergetic profiles in platelets, lymphocytes, monocytes, and neutrophils, and the oxidative burst from human blood. Lab. Investig. 2013, 93, 690-700. [CrossRef] [PubMed]

22. Al Amir Dache, Z.; Otandault, A.; Tanos, R.; Pastor, B.; Meddeb, R.; Sanchez, C.; Arena, G.; Lasorsa, L.; Bennett, A.; Grange, T.; et al. Blood contains circulating cell-free respiratory competent mitochondria. FASEB J. 2020. [CrossRef] [PubMed]

23. Spinazzi, M.; Casarin, A.; Pertegato, V.; Salviati, L.; Angelini, C. Assessment of mitochondrial respiratory chain enzymatic activities on tissues and cultured cells. Nat. Protoc. 2012, 7, 1235-1246. [CrossRef] [PubMed]

24. Hsiao, C.-P.; Hoppel, C. Analyzing mitochondrial function in human peripheral blood mononuclear cells. Anal. Biochem. 2018, 549, 12-20. [CrossRef]

25. Thannickal, V.J.; Fanburg, B.L. Reactive oxygen species in cell signaling. Am. J. Physiol. Lung Cell. Mol. Physiol. 2000, 279, L1005-L1028. [CrossRef]

26. Wallace, D.C. Diseases of the mitochondrial DNA. Annu. Rev. Biochem. 1992, 61, 1175-1212. [CrossRef]

27. Aravamudan, B.; Thompson, M.A.; Pabelick, C.M.; Prakash, Y.S. Mitochondria in lung diseases. Expert Rev. Respir. Med. 2013, 7, 631-646. [CrossRef]

28. Pan, S.; Conaway, S.J.; Deshpande, D.A. Mitochondrial regulation of airway smooth muscle functions in health and pulmonary diseases. Arch. Biochem. Biophys. 2019, 663, 109-119. [CrossRef]

29. Prakash, Y.S.; Pabelick, C.M.; Sieck, G.C. Mitochondrial dysfunction in airway disease. Chest 2017, 152, 618-626. [CrossRef]

30. Dikalov, S.; Itani, H.; Richmond, B.; Vergeade, A.; Rahman, S.M.J.; Boutaud, O.; Blackwell, T.; Massion, P.P.; Harrison, D.G.; Dikalova, A.; et al. Tobacco smoking induces cardiovascular mitochondrial oxidative stress, promotes endothelial dysfunction, and enhances hypertension. Am. J. Physiol. Heart Circ. Physiol. 2019, 316, H639-H646. [CrossRef]

31. Wiegman, C.H.; Michaeloudes, C.; Haji, G.; Narang, P.; Clarke, C.J.; Russell, K.E.; Bao, W.; Pavlidis, S.; Barnes, P.J.; Kanerva, J.; et al. Oxidative stress-induced mitochondrial dysfunction drives inflammation and airway smooth muscle remodeling in patients with chronic obstructive pulmonary disease. J. Allergy Clin. Immunol. 2015, 136, 769-780. [CrossRef] [PubMed]

32. Oka, T.; Hikoso, S.; Yamaguchi, O.; Taneike, M.; Takeda, T.; Tamai, T.; Oyabu, J.; Murakawa, T.; Nakayama, H.; Nishida, K.; et al. Mitochondrial DNA that escapes from autophagy causes inflammation and heart failure. Nature 2012, 485, 251-255. [CrossRef] [PubMed]

33. Caramori, G.; Casolari, P.; Barczyk, A.; Durham, A.L.; Di Stefano, A.; Adcock, I. COPD immunopathology. Semin. Immunopathol. 2016, 38, 497-515. [CrossRef] [PubMed] 
34. Comhair, S.A.A.; Erzurum, S.C. Antioxidant responses to oxidant-mediated lung diseases. Am. J. Physiol. Lung Cell. Mol. Physiol. 2002, 283, L246-L255. [CrossRef]

35. MacNee, W. Oxidants and COPD. Curr. Drug Targets Inflamm. Allergy 2005, 4, 627-641. [CrossRef]

36. Stevenson, C.S.; Koch, L.G.; Britton, S.L. Aerobic capacity, oxidant stress, and chronic obstructive pulmonary disease-a new take on an old hypothesis. Pharmacol. Ther. 2006, 110, 71-82. [CrossRef]

37. Kovacic, P.; Somanathan, R. Pulmonary toxicity and environmental contamination: Radicals, electron transfer, and protection by antioxidants. Rev. Environ. Contam. Toxicol. 2009, 201, 41-69. [CrossRef]

38. Colarusso, C.; Terlizzi, M.; Molino, A.; Pinto, A.; Sorrentino, R. Role of the inflammasome in chronic obstructive pulmonary disease (COPD). Oncotarget 2017, 8, 81813-81824. [CrossRef]

39. De Falco, G.; Terlizzi, M.; Sirignano, M.; Commodo, M.; D’Anna, A.; Aquino, R.P.; Pinto, A.; Sorrentino, R. Human peripheral blood mononuclear cells (PBMCs) from smokers release higher levels of IL-1-like cytokines after exposure to combustion-generated ultrafine particles. Sci. Rep. 2017, 7, 43016. [CrossRef]

40. Yang, W.; Ni, H.; Wang, H.; Gu, H. NLRP3 inflammasome is essential for the development of chronic obstructive pulmonary disease. Int. J. Clin. Exp. Pathol. 2015, 8, 13209-13216.

41. Rahman, I.; Morrison, D.; Donaldson, K.; MacNee, W. Systemic oxidative stress in asthma, COPD, and smokers. Am. J. Respir. Crit. Care Med. 1996, 154, 1055-1060. [CrossRef] [PubMed]

42. De Falco, G.; Colarusso, C.; Terlizzi, M.; Popolo, A.; Pecoraro, M.; Commodo, M.; Minutolo, P.; Sirignano, M.; D'Anna, A.; Aquino, R.P.; et al. Chronic obstructive pulmonary disease-derived circulating cells release IL-18 and. Front. Immunol. 2017, 8, 1415. [CrossRef] [PubMed]

43. Agarwal, A.R.; Kadam, S.; Brahme, A.; Agrawal, M.; Apte, K.; Narke, G.; Kekan, K.; Madas, S.; Salvi, S. Systemic Immuno-metabolic alterations in chronic obstructive pulmonary disease (COPD). Respir. Res. 2019, 20, 171. [CrossRef] [PubMed]

44. Cheng, S.-C.; Scicluna, B.P.; Arts, R.J.W.; Gresnigt, M.S.; Lachmandas, E.; Giamarellos-Bourboulis, E.J.; Kox, M.; Manjeri, G.R.; Wagenaars, J.A.L.; Cremer, O.L.; et al. Broad defects in the energy metabolism of leukocytes underlie immunoparalysis in sepsis. Nat. Immunol. 2016, 17, 406-413. [CrossRef] [PubMed]

45. Harrison, M.T.; Short, P.; Williamson, P.A.; Singanayagam, A.; Chalmers, J.D.; Schembri, S. Thrombocytosis is associated with increased short and long term mortality after exacerbation of chronic obstructive pulmonary disease: A role for antiplatelet therapy? Thorax 2014, 69, 609-615. [CrossRef]

46. Bialas, A.J.; Pedone, C.; Piotrowski, W.J.; Antonelli Incalzi, R. Platelet distribution width as a prognostic factor in patients with COPD—Pilot study. Int. J. Chronic Obstr. Pulm. Dis. 2017, 12, 2261-2267. [CrossRef]

47. Bialas, A.J.; Siewiera, K.; Watala, C.; Rybicka, A.; Grobelski, B.; Kosmider, L.; Kurek, J.; Milkowska-Dymanowska, J.; Piotrowski, W.J.; Gorski, P.; et al. Mitochondrial functioning abnormalities observed in blood platelets of chronic smoke-exposed guinea pigs-A pilot study. Int. J. Chronic Obstr. Pulm. Dis. 2018, 13, 3707-3717. [CrossRef]

48. Salve, V.T.; Atram, J.S. N-Acetylcysteine combined with home based physical activity: Effect on health related quality of life in stable COPD patients-A Randomised controlled trial. J. Clin. Diagn. Res. 2016, 10, OC16-OC19. [CrossRef]

49. Carpagnano, G.E.; Lacedonia, D.; Carone, M.; Soccio, P.; Cotugno, G.; Palmiotti, G.A.; Scioscia, G.; Foschino Barbaro, M.P. Study of mitochondrial DNA alteration in the exhaled breath condensate of patients affected by obstructive lung diseases. J. Breath Res. 2016, 10, 026005. [CrossRef]

50. Zhang, W.Z.; Rice, M.C.; Hoffman, K.L.; Oromendia, C.; Barjaktarevic, I.; Wells, J.M.; Hastie, A.T.; Labaki, W.W.; Cooper, C.B.; Comellas, A.P.; et al. Association of urine mitochondrial DNA with clinical measures of COPD in the SPIROMICS cohort. JCI Insight 2020. [CrossRef]

51. Liu, S.-F.; Kuo, H.-C.; Tseng, C.-W.; Huang, H.-T.; Chen, Y.-C.; Tseng, C.-C.; Lin, M.-C. Leukocyte Mitochondrial DNA Copy number is associated with chronic obstructive pulmonary disease. PLoS ONE 2015, 10, e0138716. [CrossRef] [PubMed]

52. Carpagnano, G.E.; Lacedonia, D.; Malerba, M.; Palmiotti, G.A.; Cotugno, G.; Carone, M.; Foschino-Barbaro, M.P. Analysis of mitochondrial DNA alteration in new phenotype ACOS. BMC Pulm. Med. 2016, 16, 31. [CrossRef] [PubMed]

53. Kim, J.-H.; Kim, H.K.; Ko, J.-H.; Bang, H.; Lee, D.-C. The relationship between leukocyte mitochondrial DNA copy number and telomere length in community-dwelling elderly women. PLoS ONE 2013, 8, e67227. [CrossRef] [PubMed] 
54. Lee, J.; Sandford, A.J.; Connett, J.E.; Yan, J.; Mui, T.; Li, Y.; Daley, D.; Anthonisen, N.R.; Brooks-Wilson, A.; Man, S.F.P.; et al. The relationship between telomere length and mortality in chronic obstructive pulmonary disease (COPD). PLoS ONE 2012, 7, e35567. [CrossRef]

55. Jin, M.; Lee, E.C.; Ra, S.W.; Fishbane, N.; Tam, S.; Criner, G.J.; Woodruff, P.G.; Lazarus, S.C.; Albert, R.; Connett, J.E.; et al. Relationship of absolute telomere length with quality of life, exacerbations, and mortality in COPD. Chest 2018, 154, 266-273. [CrossRef]

56. Pizzimenti, M.; Riou, M.; Charles, A.-L.; Talha, S.; Meyer, A.; Andres, E.; Chakfe, N.; Lejay, A.; Geny, B. The rise of mitochondria in peripheral arterial disease physiopathology: Experimental and clinical data. $J$. Clin. Med. 2019, 8. [CrossRef]

57. Lambrecht, B.N.; Hammad, H. The immunology of asthma. Nat. Immunol. 2015, 16, 45-56. [CrossRef]

58. Reddy, P.H. Mitochondrial dysfunction and oxidative stress in asthma: Implications for mitochondria-targeted antioxidant therapeutics. Pharmaceuticals 2011, 4, 429-456. [CrossRef]

59. Aguilera-Aguirre, L.; Bacsi, A.; Saavedra-Molina, A.; Kurosky, A.; Sur, S.; Boldogh, I. Mitochondrial dysfunction increases allergic airway inflammation. J. Immunol. 2009, 183, 5379-5387. [CrossRef]

60. Mabalirajan, U.; Dinda, A.K.; Kumar, S.; Roshan, R.; Gupta, P.; Sharma, S.K.; Ghosh, B. Mitochondrial structural changes and dysfunction are associated with experimental allergic asthma. J. Immunol. 2008, 181, 3540-3548. [CrossRef]

61. Sahiner, U.M.; Birben, E.; Erzurum, S.; Sackesen, C.; Kalayci, O. Oxidative stress in asthma. World Allergy Organ. J. 2011, 4, 151-158. [CrossRef] [PubMed]

62. Louhelainen, N.; Myllarniemi, M.; Rahman, I.; Kinnula, V.L. Airway biomarkers of the oxidant burden in asthma and chronic obstructive pulmonary disease: Current and future perspectives. Int. J. Chronic Obstr. Pulm. Dis. 2008, 3, 585-603.

63. Comhair, S.A.A.; Ricci, K.S.; Arroliga, M.; Lara, A.R.; Dweik, R.A.; Song, W.; Hazen, S.L.; Bleecker, E.R.; Busse, W.W.; Chung, K.F.; et al. Correlation of systemic superoxide dismutase deficiency to airflow obstruction in asthma. Am. J. Respir. Crit. Care Med. 2005, 172, 306-313. [CrossRef] [PubMed]

64. Chan, T.K.; Loh, X.Y.; Peh, H.Y.; Tan, W.N.F.; Tan, W.S.D.; Li, N.; Tay, I.J.J.; Wong, W.S.F.; Engelward, B.P. House dust mite-induced asthma causes oxidative damage and DNA double-strand breaks in the lungs. J. Allergy Clin. Immunol. 2016, 138, 84-96.e1. [CrossRef] [PubMed]

65. Leffler, J.; Read, J.F.; Jones, A.C.; Mok, D.; Hollams, E.M.; Laing, I.A.; Le Souef, P.N.; Sly, P.D.; Kusel, M.M.H.; de Klerk, N.H.; et al. Progressive increase of FcepsilonRI expression across several PBMC subsets is associated with atopy and atopic asthma within school-aged children. Pediatr. Allergy Immunol. 2019, 30, 646-653. [CrossRef]

66. Leffler, J.; Jones, A.C.; Hollams, E.M.; Prastanti, F.; Le Souef, P.N.; Holt, P.G.; Bosco, A.; Laing, I.A.; Strickland, D.H. Basophil counts in PBMC populations during childhood acute wheeze/asthma are associated with future exacerbations. J. Allergy Clin. Immunol. 2018, 142, 1639-1641.e5. [CrossRef]

67. Ederle, C.; Charles, A.-L.; Khayath, N.; Poirot, A.; Meyer, A.; Clere-Jehl, R.; Andres, E.; De Blay, F.; Geny, B. Mitochondrial function in Peripheral Blood Mononuclear Cells (PBMC) is enhanced, together with increased reactive oxygen species, in severe asthmatic patients in exacerbation. J. Clin. Med. 2019, 8. [CrossRef]

68. Clere-Jehl, R.; Helms, J.; Kassem, M.; Le Borgne, P.; Delabranche, X.; Charles, A.-L.; Geny, B.; Meziani, F.; Bilbault, P. Septic shock alters mitochondrial respiration of lymphoid cell-lines and human peripheral blood mononuclear cells: The role of plasma. Shock 2019, 51, 97-104. [CrossRef]

69. Qi, S.; Barnig, C.; Charles, A.-L.; Poirot, A.; Meyer, A.; Clere-Jehl, R.; de Blay, F.; Geny, B. Effect of nasal allergen challenge in allergic rhinitis on mitochondrial function of peripheral blood mononuclear cells. Ann. Allergy Asthma Immunol. 2017, 118, 367-369. [CrossRef]

70. Bhatraju, N.K.; Agrawal, A. Mitochondrial dysfunction linking obesity and asthma. Ann. Am. Thorac. Soc. 2017, 14, S368-S373. [CrossRef]

71. Winnica, D.; Corey, C.; Mullett, S.; Reynolds, M.; Hill, G.; Wendell, S.; Que, L.; Holguin, F.; Shiva, S. Bioenergetic differences in the airway epithelium of lean versus obese asthmatics are driven by nitric oxide and reflected in circulating platelets. Antioxid. Redox Signal 2019, 31, 673-686. [CrossRef] [PubMed]

72. Letuve, S.; Druilhe, A.; Grandsaigne, M.; Aubier, M.; Pretolani, M. Critical role of mitochondria, but not caspases, during glucocorticosteroid-induced human eosinophil apoptosis. Am. J. Respir. Cell Mol. Biol. 2002, 26, 565-571. [CrossRef] [PubMed] 
73. Idzko, M.; Pitchford, S.; Page, C. Role of platelets in allergic airway inflammation. J. Allergy Clin. Immunol. 2015, 135, 1416-1423. [CrossRef] [PubMed]

74. Rondina, M.T.; Garraud, O. Emerging evidence for platelets as immune and inflammatory effector cells. Front. Immunol. 2014, 5, 653. [CrossRef] [PubMed]

75. Averill, F.J.; Hubbard, W.C.; Proud, D.; Gleich, G.J.; Liu, M.C. Platelet activation in the lung after antigen challenge in a model of allergic asthma. Am. Rev. Respir. Dis. 1992, 145, 571-576. [CrossRef]

76. Pitchford, S.C.; Momi, S.; Baglioni, S.; Casali, L.; Giannini, S.; Rossi, R.; Page, C.P.; Gresele, P. Allergen induces the migration of platelets to lung tissue in allergic asthma. Am. J. Respir. Crit. Care Med. 2008, 177, 604-612. [CrossRef]

77. Gresele, P.; Dottorini, M.; Selli, M.L.; Iannacci, L.; Canino, S.; Todisco, T.; Romano, S.; Crook, P.; Page, C.P.; Nenci, G.G.; et al. Altered platelet function associated with the bronchial hyperresponsiveness accompanying nocturnal asthma. J. Allergy Clin. Immunol. 1993, 91, 894-902. [CrossRef]

78. Kameyoshi, Y.; Dorschner, A.; Mallet, A.I.; Christophers, E.; Schroder, J.M. Cytokine RANTES released by thrombin-stimulated platelets is a potent attractant for human eosinophils. J. Exp. Med. 1992, 176, 587-592. [CrossRef]

79. Klinger, M.H. Platelets and inflammation. Anat. Embryol. (Berl.) 1997, 196, 1-11. [CrossRef]

80. Xu, W.; Cardenes, N.; Corey, C.; Erzurum, S.C.; Shiva, S. Platelets from asthmatic individuals show less reliance on glycolysis. PLoS ONE 2015, 10, e0132007. [CrossRef]

81. Nguyen, Q.L.; Corey, C.; White, P.; Watson, A.; Gladwin, M.T.; Simon, M.A.; Shiva, S. Platelets from pulmonary hypertension patients show increased mitochondrial reserve capacity. JCI Insight 2017, 2, e91415. [CrossRef] [PubMed]

82. Nguyen, Q.L.; Wang, Y.; Helbling, N.; Simon, M.A.; Shiva, S. Alterations in platelet bioenergetics in Group 2 PH-HFpEF patients. PLoS ONE 2019, 14, e220490. [CrossRef] [PubMed]

83. Simonneau, G.; Montani, D.; Celermajer, D.S.; Denton, C.P.; Gatzoulis, M.A.; Krowka, M.; Williams, P.G.; Souza, R. Haemodynamic definitions and updated clinical classification of pulmonary hypertension. Eur. Respir. J. 2019, 53. [CrossRef] [PubMed]

84. Galie, N.; Humbert, M.; Vachiery, J.-L.; Gibbs, S.; Lang, I.; Torbicki, A.; Simonneau, G.; Peacock, A.; Vonk Noordegraaf, A.; Beghetti, M.; et al. 2015 ESC/ERS guidelines for the diagnosis and treatment of pulmonary hypertension: The joint task force for the diagnosis and treatment of pulmonary hypertension of the European Society of Cardiology (ESC) and the European Respiratory Society (ERS): Endorsed by: Association for European Paediatric and Congenital Cardiology (AEPC), International Society for Heart and Lung Transplantation (ISHLT). Eur. Respir. J. 2015, 46, 903-975. [CrossRef] [PubMed]

85. Kong, C.W.; Hsu, T.G.; Lu, F.J.; Chan, W.L.; Tsai, K. Leukocyte mitochondria depolarization and apoptosis in advanced heart failure: Clinical correlations and effect of therapy. J. Am. Coll. Cardiol. 2001, 38, 1693-1700. [CrossRef]

86. Song, B.; Li, T.; Chen, S.; Yang, D.; Luo, L.; Wang, T.; Han, X.; Bai, L.; Ma, A. Correlations between MTP and ROS levels of peripheral blood lymphocytes and readmission in patients with chronic heart failure. Heart Lung Circ. 2016, 25, 296-302. [CrossRef]

87. Kong, C.-W.; Huang, C.-H.; Hsu, T.-G.; Tsai, K.K.C.; Hsu, C.-F.; Huang, M.-C.; Chen, L.-C. Leukocyte mitochondrial alterations after cardiac surgery involving cardiopulmonary bypass: Clinical correlations. Shock 2004, 21, 315-319. [CrossRef]

88. Humbert, M.; Guignabert, C.; Bonnet, S.; Dorfmuller, P.; Klinger, J.R.; Nicolls, M.R.; Olschewski, A.J.; Pullamsetti, S.S.; Schermuly, R.T.; Stenmark, K.R.; et al. Pathology and pathobiology of pulmonary hypertension: State of the art and research perspectives. Eur. Respir. J. 2019, 53. [CrossRef]

89. Aggarwal, S.; Gross, C.M.; Sharma, S.; Fineman, J.R.; Black, S.M. Reactive oxygen species in pulmonary vascular remodeling. Compr. Physiol. 2013, 3, 1011-1034. [CrossRef]

90. Bowers, R.; Cool, C.; Murphy, R.C.; Tuder, R.M.; Hopken, M.W.; Flores, S.C.; Voelkel, N.F. Oxidative stress in severe pulmonary hypertension. Am. J. Respir. Crit. Care Med. 2004, 169, 764-769. [CrossRef]

91. Demarco, V.G.; Whaley-Connell, A.T.; Sowers, J.R.; Habibi, J.; Dellsperger, K.C. Contribution of oxidative stress to pulmonary arterial hypertension. World J. Cardiol. 2010, 2, 316-324. [CrossRef] [PubMed] 
92. Dorfmuller, P.; Chaumais, M.-C.; Giannakouli, M.; Durand-Gasselin, I.; Raymond, N.; Fadel, E.; Mercier, O.; Charlotte, F.; Montani, D.; Simonneau, G.; et al. Increased oxidative stress and severe arterial remodeling induced by permanent high-flow challenge in experimental pulmonary hypertension. Respir. Res. 2011, 12, 119. [CrossRef] [PubMed]

93. Black, S.M.; DeVol, J.M.; Wedgwood, S. Regulation of fibroblast growth factor-2 expression in pulmonary arterial smooth muscle cells involves increased reactive oxygen species generation. Am. J. Physiol. Cell. Physiol. 2008, 294, C345-C354. [CrossRef] [PubMed]

94. Dromparis, P.; Sutendra, G.; Michelakis, E.D. The role of mitochondria in pulmonary vascular remodeling. J. Mol. Med. (Berl.) 2010, 88, 1003-1010. [CrossRef]

95. Dromparis, P.; Michelakis, E.D. Mitochondria in vascular health and disease. Annu. Rev. Physiol. 2013, 75, 95-126. [CrossRef]

96. Gomez-Arroyo, J.; Mizuno, S.; Szczepanek, K.; Van Tassell, B.; Natarajan, R.; dos Remedios, C.G.; Drake, J.I.; Farkas, L.; Kraskauskas, D.; Wijesinghe, D.S.; et al. Metabolic gene remodeling and mitochondrial dysfunction in failing right ventricular hypertrophy secondary to pulmonary arterial hypertension. Circ. Heart Fail 2013, 6, 136-144. [CrossRef]

97. Redout, E.M.; Wagner, M.J.; Zuidwijk, M.J.; Boer, C.; Musters, R.J.P.; van Hardeveld, C.; Paulus, W.J.; Simonides, W.S. Right-ventricular failure is associated with increased mitochondrial complex II activity and production of reactive oxygen species. Cardiovasc. Res. 2007, 75, 770-781. [CrossRef]

98. Graham, B.B.; Kumar, R.; Mickael, C.; Sanders, L.; Gebreab, L.; Huber, K.M.; Perez, M.; Smith-Jones, P.; Serkova, N.J.; Tuder, R.M. Severe pulmonary hypertension is associated with altered right ventricle metabolic substrate uptake. Am. J. Physiol. Lung Cell. Mol. Physiol. 2015, 309, L435-L440. [CrossRef]

99. Piao, L.; Marsboom, G.; Archer, S.L. Mitochondrial metabolic adaptation in right ventricular hypertrophy and failure. J. Mol. Med. (Berl.) 2010, 88, 1011-1020. [CrossRef]

100. Malenfant, S.; Potus, F.; Fournier, F.; Breuils-Bonnet, S.; Pflieger, A.; Bourassa, S.; Tremblay, E.; Nehme, B.; Droit, A.; Bonnet, S.; et al. Skeletal muscle proteomic signature and metabolic impairment in pulmonary hypertension. J. Mol. Med. (Berl.) 2015, 93, 573-584. [CrossRef]

101. Riou, M.; Pizzimenti, M.; Enache, I.; Charloux, A.; Canuet, M.; Andres, E.; Talha, S.; Meyer, A.; Geny, B. Skeletal and respiratory muscle dysfunctions in pulmonary arterial hypertension. J. Clin. Med. 2020, 9. [CrossRef] [PubMed]

102. Diebold, I.; Hennigs, J.K.; Miyagawa, K.; Li, C.G.; Nickel, N.P.; Kaschwich, M.; Cao, A.; Wang, L.; Reddy, S.; Chen, P.-I.; et al. BMPR2 preserves mitochondrial function and DNA during reoxygenation to promote endothelial cell survival and reverse pulmonary hypertension. Cell Metab. 2015, 21, 596-608. [CrossRef] [PubMed]

103. Chandel, N.S.; McClintock, D.S.; Feliciano, C.E.; Wood, T.M.; Melendez, J.A.; Rodriguez, A.M.; Schumacker, P.T. Reactive oxygen species generated at mitochondrial complex III stabilize hypoxia-inducible factor-1alpha during hypoxia: A mechanism of O2 sensing. J. Biol. Chem. 2000, 275, 25130-25138. [CrossRef] [PubMed]

104. Block, K.; Gorin, Y.; Hoover, P.; Williams, P.; Chelmicki, T.; Clark, R.A.; Yoneda, T.; Abboud, H.E. NAD(P)H oxidases regulate HIF-2alpha protein expression. J. Biol. Chem. 2007, 282, 8019-8026. [CrossRef]

105. Cheng, T.H.; Shih, N.L.; Chen, S.Y.; Loh, S.H.; Cheng, P.Y.; Tsai, C.S.; Liu, S.H.; Wang, D.L.; Chen, J.J. Reactive oxygen species mediate cyclic strain-induced endothelin-1 gene expression via Ras/Raf/extracellular signal-regulated kinase pathway in endothelial cells. J. Mol. Cell. Cardiol. 2001, 33, 1805-1814. [CrossRef]

106. Tate, R.M.; Morris, H.G.; Schroeder, W.R.; Repine, J.E. Oxygen metabolites stimulate thromboxane production and vasoconstriction in isolated saline-perfused rabbit lungs. J. Clin. Investig. 1984, 74, 608-613. [CrossRef]

107. Lee, D.S.; McCallum, E.A.; Olson, D.M. Effects of reactive oxygen species on prostacyclin production in perinatal rat lung cells. J. Appl. Physiol. (1985) 1989, 66, 1321-1327. [CrossRef]

108. Chaumais, M.-C.; Ranchoux, B.; Montani, D.; Dorfmuller, P.; Tu, L.; Lecerf, F.; Raymond, N.; Guignabert, C.; Price, L.; Simonneau, G.; et al. N-acetylcysteine improves established monocrotaline-induced pulmonary hypertension in rats. Respir. Res. 2014, 15, 65. [CrossRef]

109. Liu, M.; Wang, Y.; Zheng, L.; Zheng, W.; Dong, K.; Chen, S.; Zhang, B.; Li, Z. Fasudil reversed MCT-induced and chronic hypoxia-induced pulmonary hypertension by attenuating oxidative stress and inhibiting the expression of Trx1 and. Respir. Physiol. Neurobiol. 2014, 201, 38-46. [CrossRef] 
110. Mittal, M.; Roth, M.; Konig, P.; Hofmann, S.; Dony, E.; Goyal, P.; Selbitz, A.-C.; Schermuly, R.T.; Ghofrani, H.A.; Kwapiszewska, G.; et al. Hypoxia-dependent regulation of nonphagocytic NADPH oxidase subunit NOX4 in the pulmonary vasculature. Circ. Res. 2007, 101, 258-267. [CrossRef]

111. Vignais, P.V. The superoxide-generating NADPH oxidase: Structural aspects and activation mechanism. Cell. Mol. Life Sci. 2002, 59, 1428-1459. [CrossRef] [PubMed]

112. Babior, B.M. The NADPH oxidase of endothelial cells. IUBMB Life 2000, 50, 267-269. [CrossRef]

113. Cheng, Y.; Ren, X.; Gowda, A.S.P.; Shan, Y.; Zhang, L.; Yuan, Y.-S.; Patel, R.; Wu, H.; Huber-Keener, K.; Yang, J.W.; et al. Interaction of Sirt3 with OGG1 contributes to repair of mitochondrial DNA and protects from apoptotic cell death under oxidative stress. Cell Death Dis. 2013, 4, e731. [CrossRef] [PubMed]

114. Paulin, R.; Dromparis, P.; Sutendra, G.; Gurtu, V.; Zervopoulos, S.; Bowers, L.; Haromy, A.; Webster, L.; Provencher, S.; Bonnet, S.; et al. Sirtuin 3 deficiency is associated with inhibited mitochondrial function and pulmonary arterial hypertension in rodents and humans. Cell Metab. 2014, 20, 827-839. [CrossRef] [PubMed]

115. Zanjani, K.S. Platelets in pulmonary hypertension: A causative role or a simple association? Iran J. Pediatr. 2012, 22, 145-157.

116. Johnson, S.R.; Granton, J.T.; Mehta, S. Thrombotic arteriopathy and anticoagulation in pulmonary hypertension. Chest 2006, 130, 545-552. [CrossRef]

117. D'Souza, S.P.; Yellon, D.M.; Martin, C.; Schulz, R.; Heusch, G.; Onody, A.; Ferdinandy, P.; Baxter, G.F. B-type natriuretic peptide limits infarct size in rat isolated hearts via KATP channel opening. Am. J. Physiol. Heart Circ. Physiol. 2003, 284, H1592-H1600. [CrossRef]

118. Talha, S.; Bouitbir, J.; Charles, A.-L.; Zoll, J.; Goette-Di Marco, P.; Meziani, F.; Piquard, F.; Geny, B. Pretreatment with brain natriuretic peptide reduces skeletal muscle mitochondrial dysfunction and oxidative stress after ischemia-reperfusion. J. Appl. Physiol. (1985) 2013, 114, 172-179. [CrossRef]

119. Lederer, D.J.; Martinez, F.J. Idiopathic pulmonary fibrosis. N. Engl. J. Med. 2018, 378, 1811-1823. [CrossRef]

120. Lopez-Otin, C.; Blasco, M.A.; Partridge, L.; Serrano, M.; Kroemer, G. The hallmarks of aging. Cell 2013, 153, 1194-1217. [CrossRef]

121. Schafer, M.J.; White, T.A.; Iijima, K.; Haak, A.J.; Ligresti, G.; Atkinson, E.J.; Oberg, A.L.; Birch, J.; Salmonowicz, H.; Zhu, Y.; et al. Cellular senescence mediates fibrotic pulmonary disease. Nat. Commun. 2017, 8, 14532. [CrossRef] [PubMed]

122. Negmadjanov, U.; Godic, Z.; Rizvi, F.; Emelyanova, L.; Ross, G.; Richards, J.; Holmuhamedov, E.L.; Jahangir, A. TGF-beta1-mediated differentiation of fibroblasts is associated with increased mitochondrial content and cellular respiration. PLoS ONE 2015, 10, e0123046. [CrossRef] [PubMed]

123. Jain, M.; Rivera, S.; Monclus, E.A.; Synenki, L.; Zirk, A.; Eisenbart, J.; Feghali-Bostwick, C.; Mutlu, G.M.; Budinger, G.R.S.; Chandel, N.S.; et al. Mitochondrial reactive oxygen species regulate transforming growth factor-beta signaling. J. Biol. Chem. 2013, 288, 770-777. [CrossRef] [PubMed]

124. Martinez, F.J.; de Andrade, J.A.; Anstrom, K.J.; King, T.E.J.; Raghu, G. Randomized trial of acetylcysteine in idiopathic pulmonary fibrosis. N. Engl. J. Med. 2014, 370, 2093-2101. [CrossRef]

125. Heukels, P.; van Hulst, J.A.C.; van Nimwegen, M.; Boorsma, C.E.; Melgert, B.N.; van den Toorn, L.M.; Boomars, K.A.T.; Wijsenbeek, M.S.; Hoogsteden, H.; von der Thusen, J.H.; et al. Fibrocytes are increased in lung and peripheral blood of patients with idiopathic pulmonary fibrosis. Respir. Res. 2018, 19, 90. [CrossRef]

126. Sode, B.F.; Dahl, M.; Nielsen, S.F.; Nordestgaard, B.G. Venous thromboembolism and risk of idiopathic interstitial pneumonia: A nationwide study. Am. J. Respir. Crit. Care Med. 2010, 181, 1085-1092. [CrossRef]

127. Hubbard, R.B.; Smith, C.; Le Jeune, I.; Gribbin, J.; Fogarty, A.W. The association between idiopathic pulmonary fibrosis and vascular disease: A population-based study. Am. J. Respir. Crit. Care Med. 2008, 178, 1257-1261. [CrossRef]

128. Leopold, J.A.; Maron, B.A. Molecular mechanisms of pulmonary vascular remodeling in pulmonary arterial hypertension. Int. J. Mol. Sci. 2016, 17. [CrossRef]

129. Ryan, J.; Dasgupta, A.; Huston, J.; Chen, K.-H.; Archer, S.L. Mitochondrial dynamics in pulmonary arterial hypertension. J. Mol. Med. (Berl.) 2015, 93, 229-242. [CrossRef]

130. Mizumura, K.; Cloonan, S.M.; Nakahira, K.; Bhashyam, A.R.; Cervo, M.; Kitada, T.; Glass, K.; Owen, C.A.; Mahmood, A.; Washko, G.R.; et al. Mitophagy-dependent necroptosis contributes to the pathogenesis of COPD. J. Clin. Investig. 2014, 124, 3987-4003. [CrossRef]

131. Ten, V.S.; Ratner, V. Mitochondrial bioenergetics and pulmonary dysfunction: Current progress and future directions. Paediatr. Respir. Rev. 2019. [CrossRef] [PubMed] 
132. Thannickal, V.J.; Toews, G.B.; White, E.S.; Lynch, J.P., 3rd; Martinez, F.J. Mechanisms of pulmonary fibrosis. Annu. Rev. Med. 2004, 55, 395-417. [CrossRef] [PubMed]

133. Xie, N.; Tan, Z.; Banerjee, S.; Cui, H.; Ge, J.; Liu, R.-M.; Bernard, K.; Thannickal, V.J.; Liu, G. Glycolytic Reprogramming in Myofibroblast Differentiation and Lung Fibrosis. Am. J. Respir. Crit. Care Med. 2015, 192, 1462-1474. [CrossRef] [PubMed]

134. Schuliga, M.; Pechkovsky, D.V.; Read, J.; Waters, D.W.; Blokland, K.E.C.; Reid, A.T.; Hogaboam, C.M.; Khalil, N.; Burgess, J.K.; Prele, C.M.; et al. Mitochondrial dysfunction contributes to the senescent phenotype of IPF lung fibroblasts. J. Cell. Mol. Med. 2018, 22, 5847-5861. [CrossRef] [PubMed]

135. Manevski, M.; Muthumalage, T.; Devadoss, D.; Sundar, I.K.; Wang, Q.; Singh, K.P.; Unwalla, H.J.; Chand, H.S.; Rahman, I. Cellular stress responses and dysfunctional Mitochondrial-cellular senescence, and therapeutics in chronic respiratory diseases. Redox Biol. 2020, 101443. [CrossRef] [PubMed]

136. Jablonski, R.P.; Kim, S.-J.; Cheresh, P.; Williams, D.B.; Morales-Nebreda, L.; Cheng, Y.; Yeldandi, A.; Bhorade, S.; Pardo, A.; Selman, M.; et al. SIRT3 deficiency promotes lung fibrosis by augmenting alveolar epithelial cell mitochondrial DNA damage and apoptosis. FASEB J. 2017, 31, 2520-2532. [CrossRef]

137. Li, Y.; Ma, Y.; Song, L.; Yu, L.; Zhang, L.; Zhang, Y.; Xing, Y.; Yin, Y.; Ma, H. SIRT3 deficiency exacerbates p53/Parkinmediated mitophagy inhibition and promotes mitochondrial dysfunction: Implication for aged hearts. Int. J. Mol. Med. 2018, 41, 3517-3526. [CrossRef]

138. Sanders, K.A.; Hoidal, J.R. The NOX on pulmonary hypertension. Circ. Res. 2007, 101, 224-226. [CrossRef]

139. Chen, X.; Yao, J.-M.; Fang, X.; Zhang, C.; Yang, Y.-S.; Hu, C.-P.; Chen, Q.; Zhong, G.-W. Hypoxia promotes pulmonary vascular remodeling via HIF-1alpha to regulate mitochondrial dynamics. J. Geriatr. Cardiol. 2019, 16, 855-871. [CrossRef]

140. Jaitovich, A.; Jourd'heuil, D. A brief overview of nitric oxide and reactive oxygen species signaling in hypoxia-induced pulmonary hypertension. Adv. Exp. Med. Biol. 2017, 967,71-81. [CrossRef]

141. Sun, T.; Liu, J.; Zhao, D.W. Efficacy of N-acetylcysteine in idiopathic pulmonary fibrosis: A systematic review and meta-analysis. Medicine (Baltimore) 2016, 95, e3629. [CrossRef] [PubMed]

142. Sharp, J.; Farha, S.; Park, M.M.; Comhair, S.A.; Lundgrin, E.L.; Tang, W.H.W.; Bongard, R.D.; Merker, M.P.; Erzurum, S.C. Coenzyme Q supplementation in pulmonary arterial hypertension. Redox Biol. 2014, 2, 884-891. [CrossRef] [PubMed]

143. Missiroli, S.; Genovese, I.; Perrone, M.; Vezzani, B.; Vitto, V.A.M.; Giorgi, C. The Role of mitochondria in inflammation: From cancer to neurodegenerative disorders. J. Clin. Med. 2020, 9. [CrossRef] [PubMed]

144. Gu, X.; Wu, G.; Yao, Y.; Zeng, J.; Shi, D.; Lv, T.; Luo, L.; Song, Y. Intratracheal administration of mitochondrial DNA directly provokes lung inflammation through the TLR9-p38 MAPK pathway. Free Radic Biol. Med. 2015, 83, 149-158. [CrossRef] [PubMed]

145. Benmerzoug, S.; Ryffel, B.; Togbe, D.; Quesniaux, V.F.J. Self-DNA Sensing in lung inflammatory diseases. Trends Immunol. 2019, 40, 719-734. [CrossRef]

(C) 2020 by the authors. Licensee MDPI, Basel, Switzerland. This article is an open access article distributed under the terms and conditions of the Creative Commons Attribution (CC BY) license (http://creativecommons.org/licenses/by/4.0/). 